\title{
The Role of Supervisors in Employee Unions
}

Supervisors play a central role in labor relations as the link between management and employees. ${ }^{1}$ An employer communicates with, directs, and monitors the work of rank and file employees through its supervisors and often entrusts to them the resolution of employee grievances. Because the successful operation of a firm often depends on the supervisors' effective performance of these functions, management has a great interest in securing their loyalty. At the same time, employees under a supervisor's direction desire his support because of the effects his actions can have both on individual employees and on employees' group efforts. Employees whose economic lives are influenced by a supervisor's decisions may seek to influence him through common associations. This may become particularly important in bargaining or impasse situations. The ability of rank and file employees to improve their wages and working conditions beyond the level that their employer would voluntarily set depends largely on their ability to prevent the employer's business from functioning until their demands are met. To the extent that supervisors can maintain operations, even at a reduced level, employee unions need their support to be fully effective.

Because of their unique position in the labor-management structure, supervisors may view the benefits of adherence to employee unions differently from other employees. ${ }^{2}$ Employers may consider the degree of supervisors' identification with management interests in determining the rapidity of their advancement. At the same time, supervisorsparticularly low-level supervisors-share with other employees certain interests in retaining union affiliation: financial benefits, such as union pensions and health and welfare payments, and friendships with other union members.

The conflicting demands on supervisors' loyalty and the consequent, potential conflicts between their interests and those of other employees become particularly problematic when supervisors retain membership in rank and file unions. This comment discusses the congressional, administrative, and judicial response to two questions that have arisen

1 See generally Larrowe, $A$ Meteor on the Industrial Relations Horizon: The Foreman's Association of America, 2 LAB. HIST. 259 (1961); Levinson, Foremen's Unions and the Law, 1950 Wrs. L. REv. 79.

2 See Getman, The Protection of Economic Pressure by Section 7 of the National Labor Relations Act, 115 U. PA. L. Rev. 1195, 1213 (1967). 
when supervisors belong to employee-dominated unions. First, to what extent may unions discipline supervisors in order to enforce their loyalty to union decisions? Second, to what extent should supervisors be allowed to participate in union decision making? As a result of the National Labor Relations Board's decisions, these two questions have become closely interrelated. In its decisions on union discipline, the Board, relying on a section of the statute not supporting the results it has reached, may have altered the interests that it had previously balanced in order to define the permissible scope of supervisor participation in union affairs. This comment suggests ways of clarifying the Board's approach to these problems.

\section{Provisions of the Taft-Hartrey Act}

Prior to 1947, the National Labor Relations $\mathrm{Act}^{3}$ had no provision explicitly defining the status of supervisors. There was considerable dispute as to whether they were included within the generic term "employer," which was defined in the Act as "any person acting in the interests of an employer . .."; 4 if supervisors were employers, they were not entitled to the protections accorded employees by the Act. The National Labor Relations Board, after several changes of opinion, concluded that, generally, supervisors were entitled to the rights of organization and collective bargaining guaranteed to employees. 5

Many Congressmen disagreed with this interpretation of the Act, but a bill excluding supervisors from the definition of employee was vetoed by President Truman. ${ }^{6}$ During the debate preceding adoption of the

3 Ch. 372, §§ 1 et seq., 49 Stat. 440 (1935), as amended, 29 U.S.C. $\S \S 141$ et seq. (1970).

4 Ch. $372, \& 2(2), 49$ Stat. 450 (1935), as amended 29 U.S.C. $\$ 2(2)$ (1970).

5 Union Collieries Coal Co., 41 N.L.R.B. 961, 10 L.R.R.M. 140 (1942); Godchaux Sugars, Inc., 44 N.C.R.B. 874, 11 L.R.R.M. 122 (1942); Maryland Drydock Co., 49 N.L.R.B. 733, 12 L.R.R.M. 126 (1943); Packard Motor Car Co., 64 N.L.R.B. 1212, 17 L.R.R.M. 163 (1945), enforced, 157 F.2d 80 (6th Cir. 1946), aff'd, 330 U.S. 485 (1947); Jones \& Laughlin Steel Corp., 66 N.L.R.B. 386, 17 L.R.R.M. 304 (1946); see H.R. REP. No. 245, 80th Cong., Ist Sess. 13 (1947), 1 Legislative History of the Labor Management Relations Act of 1947304 (1948) [hereinafter cited as LeGrSLATIVE HistoRY of LMRA]. For a critical analysis of the rights of supervisors prior to the adoption of the Taft-Hartley amendments, see Comment, Rights of Supervisory Employees To Collective Bargaining Under the $\mathrm{Na}$ tional Labor Relations Act, 55 YALE L.J. 754 (1946).

( H.R. 4908, 80th Cong., 1st Sess. (1947), the so-called Case bill, would have excluded supervisors from the protection of the National Labor Relations Act. H.R. REP. No. 245, 80th Cong., Ist Sess. 13 (1947), I Legrslative History of LMRA, supra note 5, at 305. Two earlier efforts to deal with the problem were also unsuccessful: H.R. 2239, 78th Cong., 1st Sess. (1943) (excluding foremen from the provisions of the statute); H.R. 1996 78th Cong., Ist Sess. (1943) (excluding from the term "employee" executive, administrative and supervisory employees). Comment, supra note 5, at $766 \mathrm{nn}$. 66-67. See also Levinson, supra note 1 , at 95 . 
1947 amendments, two alternative treatments under the Act were advocated. The majority of the House Committee on Labor and Education recommended that supervisors be excluded from the protections of the Act, ${ }^{7}$ urging that the employer's need for loyal supervisory personnel $l^{8}$ outweighed the organizational interests of the supervisors. The minority on the Committee favored according supervisors organizational and bargaining rights, arguing that a prohibition against association with rank and file organizations would be sufficient to protect the employers' legitimate interests. ${ }^{9}$

The Taft-Hartley Act, ${ }^{10}$ which emerged from this debate, excludes supervisors from the definition of the term "employee,"11 enabling employers to condition supervisors' employment upon nonmembership in the union or nonparticipation in union affairs. ${ }^{12}$ Nevertheless, the law does not ban supervisors from wholly supervisory unions or from those including, or even dominated by, rank and file employees. ${ }^{13}$ Employers may agree to negotiate with the union concerning the supervisors' conditions of employment, but they cannot be compelled by federal or state authority to do so. ${ }^{14}$

7 H.R. REP. No. 245, 80th Cong., 1st Sess. 14 (1947), 1 Legrslative History of LMRA supra note 5 , at 305 .

8 H.R. Rep. No. 245, 80th Cong., Ist Sess. 16 (1947), I Legislative History of LMRA supra note 5 , at 307 .

9 See 93 Cong. Rec. 5138 (1947), 2 Legislative History of LMRA, supra note 5, at 1480 (remarks of Senator Hatch).

10 Labor-Management Relations Act (Taft-Hartley Act), §§ 1-47, 29 U.S.G. \$§ 141-87 (1970), amending 49 Stat. 449 (1935) [hereinafter cited as LMRA]. For a discussion of the impact of this legislation on a strike in process when it was passed, see Levinson, supra note 1 , at 94 .

11 LMRA § 2(3), 29 U.S.C. § 152(3) (1970).

12 Although supervisors are not accorded the protection of the Act, the Board, on occasion, has found section $8(a)(1)$ violations for discharges of supervisors because of the alleged impact on the rank and file employees. E.g., Talladega Cotton Factory, 106 N.L.R.B. 295, 32 L.R.R.M. 1479 (1953), enforced, 213 F.2d 391 (5th Cir. 1954); see C. Morris, The Developing Labor LAw 774 (1971); Johannesen, Continuing Controversy: New Remedies for Old Unfair Labor Practices, 23 LAB. L.J. 100, 107-10 (1972). Compare the treatment accorded supervisory employees by statutes governing labor-management relations in the public sector, Rains, Collective Bargaining in the Public Sector and the Need for Exclusion of Supervisory Employees, 23 LAB. L.J. 275 (1972).

13 LMRA § 14(a), 29 U.S.C. § 164(a) provides that "[n]othing herein shall prohibit any individual employed as a supervisor from becoming or remaining a member of a labor organization ...."

14 LMRA \& 14(a), 29 U.S.C. \& 164(a) (1970) concludes: "No employer subject to this [Act] shall be compelled to deem individuals defined herein as supervisors as employees for the purpose of any law, either national or local, relating to collective bargaining." Thus, the NLRB may not include supervisors in Board certified units. See LMRA §§ 9(a), 14(a), 29 U.S.G. \$\$ 159(a), 164(a) (1970); Sakrete, Inc. v. NLRB, 332 F.2d 902, 908 (9th Cir. 1964), cert. denied, 379 U.S. 961 (1965). C. MoRRIs, supra note 12, at 205. Nor may a union condition the signing of a contract applicable to employees covered by the Act 
The Act, however, provides little guidance for resolving two problems that frequently occur when unions that represent both supervisory and rank and file members are recognized. Section $8(b)(1)(B)^{15}$ prohibits unions from coercing or restraining employers in selection of representatives for purposes of grievance adjustment or collective bargaining, but leaves unanswered the questions of the extent to which unions may discipline supervisor-members and the extent to which supervisormembers may participate in union decision making. The NLRB and the courts have treated these as independent problems.

\section{UNION Discipline OF SUPERVISORS}

A union's effectiveness is directly related to the support it receives from employees. To encourage that support, unions apply to recalcitrant members a variety of sanctions, including fines, suspension and expulsion. The effectiveness of suspension or expulsion as a sanction has been diminished by decisions that preserve the employee's job status when he has been suspended or expelled for reasons other than failure to pay regular dues and initiation fees, even though a valid union security claưse requiring all employees to be union members had been negotiated with the employer. ${ }^{16}$ Since 1967 , however, effectiveness of fines as a sanction has increased as a result of the Supreme Court's ruling in NLRB v. Allis-Chalmers Manufacturing Co..$^{17}$ that fines imposed by unions can, if they are reasonable, be enforced in the courts. In AllisChalmers, an employee-member who had participated in the union strike vote was fined for crossing the picket line set up during the subsequent strike. Over the dissent of four justices, the Court rejected the employer's contention that such fines coerced the employees in violation of section $8(\mathrm{~b})(1)(\mathrm{A})$ of the Act. ${ }^{18}$

upon the employer's willingness to bargain with supervisors. See, e.g., NLRB v. Retail Clerks Int'l Ass'n (Safeway Co.), 203 F.2d 165 (9th Gir. 1953) (holding the union in contempt for insisting on bargaining for supervisors in violation of a consent decree), enforcing 96 N.L.R.B. 581, 28 L.R.R.M. 1554 (1951), cert. denied, 848 U.S. 839 (1954); Southern Cal. Pipe Trades Dist. Council 16 (Aero Plumbing Co.), 167 N.L.R.B. 1004, 66 L.R.R.M. 1233 (1967). See also C. MoRrIs, supra note 12, at 428. Despite these rules, however, some unions have been able to establish de facto bargaining units that include supervisors, and occasionally have negotiated successfully for union security provisions applicable to supervisors. See, e.g., San Francisco-Oakland Mailers' Local 18 (Northwest Publications, Inc.), 172 N.L.R.B. No. 252, 69 L.R.R.M. 1157 (1968). See also Rosenthal, Taft-Hartley Limitations on Union Security, 4 LAB. L.J. 663, 671-72 (1953).

1529 U.S.C. $\$ 158(\mathrm{~b})(\mathrm{l})(\mathrm{B})(1970)$.

16 LMRA \& 8(a)(3), 29 U.S.C. § I58(a)(3) (1970); Radio Officers' Union v. NLRB, 347 U.S. 17,40 (1954). 17388 U.S. 175 (1967).

18 LMRA § $8(\mathrm{~b})(\mathrm{l})(\mathrm{A})$, 29 U.S.C. § 158(b)(1)(A) provides: "It shall be an unfair labor 
After Allis-Ghalmers announced that section $8(\mathrm{~b})(1)(\mathrm{A})$ does not bar unions from disciplining employee-members who have violated valid union rules and decisions, ${ }^{19}$ the NLRB was asked to determine if such discipline, when directed at supervisor-members, violates the Act. ${ }^{20}$ In performing his job, the supervisor may often find it necessary to take actions that are distasteful to some employees and contrary to the union's constitution or bylaws. The ability of the union to discipline supervisors for such actions may inhibit management's operation of the business. Of course, under the Taft-Hartley Act, the employer does not have unfettered discretion in its conduct of the business and is obliged to bargain with validly established unions concerning employees' wages and conditions of employment. ${ }^{21}$ The resultant collective bargaining agreement establishes limitations on employer prerogatives, enforceable through judicial proceedings and, if the contract provides, through grievance and arbitration mechanisms. Union attempts to discipline supervisors, when the offending action concerns the supervisors' employment activities, may circumvent these established procedures or create restrictions on employer conduct that the union was unable to obtain at the bargaining table.

practice for a labor organization or its agents ... to restrain or coerce . . employees in the exercise of the rights guaranteed in section 7: Provided, That this paragraph shall not impair the right of a labor organization to prescribe its own rules with respect to the acquisition or retention of membership therein ...."

10 For later applications of the Allis-Chalmers position, see Scofield v. NLRB, 394 U.S. 423 (1969); NLRB v. Marine \& Shipbldg. Workers, 391 U.S. 418 (1968). Rocket Freight Lines Co. v. NLRB, 427 F.2d 202 (10th Gir.), cert. denied, 400 U.S. 942 (1970). But see NLRB v. Granite State Joint Bd. - U.S. -, 93 S. Ct. 385 (1972), holding that the union had committed an unfair labor practice by fining former employee-members who had resigned during a valid strike and returned to work. Neither the employment contract nor the union's constitution limited a member's right to resign from the union, and the Court implied that the result might have been different had such limitations existed. See 85 HARv. L. REv. 1669 (1972). See generally, Gould, Some Limitations Upon Union Discipline Under the National Labor Relations Act: The Radiations of Allis-Chalmers, 1970 DURE L.J. 1067.

20 This question was considered in two cases arising prior to Allis-Chalmers in which unions had insisted on a contract provision requiring that supervisors be union members and struck when employers refused to agree. In affirming the Board's finding of a section $8(b)(1)(B)$ violation in the first case, International Typographical Local 38 (Faverhill Gazette Co.) v. NLRB, 278 F.2d 6 (Ist Cir. 1960), modifying 123 N.L.R.B. 806, 43 L.R.R.M. 1538 (1959), affd, 365 U.S. 705 (1961) (divided Court), the First Circuit noted that the provision "would also give the unions power to force the discharge or demotion of a foreman by expelling him from the union." Id. at 12. In the second case, Portland Stereotypers Local 48 (Journal Publishing Co. \& Oregonian Publishing Co.), 137 N.L.R.B. 782, 787, 50 L.R.R.M. 1259, 1261 (1962), the Board expressly relied on the First Circuit's opinion in the Haverhill Gazette case. Lithographers Locals 15-P \& 272 (Toledo Blade Co.), 175 N.L.R.B. 1072, 71 L.R.R.M. 1467 (1969), enforced, 437 F.2d 55 (6th Cir. 1971).

21 LMRA § 8(a)(5), 29 U.S.C. § 158(a)(5) (1970). 
- The NLRB has confronted this problem in a number of cases. Instead of instituting grievance proceedings or using other statutorily approved mechanisms ${ }^{22}$ for remedying contract violations, unions had fined or expelled supervisors for violating contract provisions-for working with an undermanned crew, ${ }^{23}$ performing duties outside his job classification, ${ }^{24}$ discriminating against an employee who is a fellow union member, ${ }^{25}$ commencing work prior to the scheduled hour, ${ }^{26}$ and for failing to attend a union hearing concerning the supervisor's alleged violation. ${ }^{27}$ In such cases, the Board has found that a union's use of disciplinary measures as a means of controlling an employer's business operations violates section $8(\mathrm{~b})(1)(\mathrm{B})$ of the Act. This section provides that it is an unfair labor practice for a union to "restrain or coerce ... an employer in the selection of his representatives for purposes of collective bargaining or the adjustment of grievances." The section does not deal specifically with the propriety of or limitations on union discipline of supervisor-members. Rather, it was enacted in order to prevent a certain union bargaining tacticobjection by a union to the particular individuals whom the employer had chosen to represent him. ${ }^{28}$ It was designed to accord employers the right, already granted to employees under section 7, "to choose whomever they wish to represent them in formal labor negotiations." 29

The NLRB first used section $8(b)(1)(B)$ to prohibit conduct other than that clearly within the section's intended scope in San FranciscoOakland Mailers' Local $18 . .^{30}$ In that case, the union fined supervisormembers for failure to appear before its executive committee to explain alleged contract violations, including use of an assistant foreman to repair a machine and permitting nonunion members to engage in bargaining unit work. The Board found this a violation of section $8(\mathrm{~b})(\mathrm{l})(\mathrm{B})$. It reasoned that, while the union had not tried to force a

22 LMRA § 301(a), 29 U.S.C. § 185 (1970); see G. MoRRIs, supra note 12, at 440-79.

23 Lithographers Locals 15-P \& 272 (Toledo Blade Co.), 175 N.L.R.B. 1072, 71 L.R.R.M. 1467 (1969), enforced, 437 F.2d 55 (6th Cir. 1971).

24 Teamsters Local 287 (Grinnel Co.), 183 N.L.R.B. No. 49, 74 L.R.R.M. 1354 (1970).

25 Dallas Mailers Local 143 (Dow Jones Co.), 181 N.L.R.B. 286, 73 L.R.R.M. 1360 (1970), enforced, 445 F.2d 730 (D.C. Cir. 1971).

26 Sheet Metal Workers Local 49 (General Metal Prods., Inc.), 178 N.L.R.B. 139, 72 L.R.R.M. 1070 (1969), enforced, 430 F.2d 1348 (10th Cir. 1970).

27 San Francisco-Oakland Mailers' Local 18, (Northwest Publications, Inc.), 172 N.L.R.B. No, 252, 69 L.R.R.M. 1157 (1968).

2893 Cong. Rec. 3953 (1947), I Legrslative History of LMRA, supra note 5, at 1012 (remarks of Senator Taft).

29 General Elec. Co. v. NLRB, 412 F.2d 512, 516 (2d Cir. 1969).

30 San Francisco-Oakland Mailers' Local 18 (Northwest Publications, Inc.), 172 N.L.R.B No. 252, 69 L.R.R.M. 1157 (1968). 
substitution of negotiating personnel as $8(\mathrm{~b})(1)(\mathrm{B})$ explicitly outlawed, it had "sought the substitution of attitudes rather than persons," 31 and had imposed pressure on the employer's grievance representatives to achieve that end. The Board concluded that such action was the functional equivalent of the union's assertion of control over the identity of the employer's grievance representatives since the employer "would have to replace its foreman or face de facto non-representation by them."32

Shortly after its decision in San Francisco-Oakland Mailers', the Board, in Syd Gough of Sons, Inc., ${ }^{33}$ refused to find a violation of $8(\mathrm{~b})(1)(\mathrm{B})$ when a union fined a supervisor-member for failure to comply with a union rule requiring a member of a sister local to register with the local union before working in its district. The Board dismissed the employer's complaint, finding that discipline for infraction of this housekeeping rule did not give the union a veto over the supervisor's job selection or employment decisions and, therefore, affected only the union-union member relationship. ${ }^{34}$

In Syd Gough of Sons, the Board thus refused to apply section $8(\mathrm{~b})(1)(B)$ to discipline that in no way affects the employer's business conduct. In subsequent cases, however, once it has found that the union's discipline is intended to affect union-employer relations, the Board has given the section a broad application. ${ }^{35}$ The section is, by

31 I72 N.L.R.B. No. 252, at 3, 69 L.R.R.M. at 1159.

32 Id., 69 L.R.R.M. at 1159. In its opinion, the Board made reference to Senator Ellender's remarks during the congressional debate regarding section $8(b)(1)(B)$ : " [Q]uite a few unions forced employers to change foremen. They have been taking it upon themselves to say that management should not appoint any representative who is too strict with the membership of the union. This amendment seeks to prescribe a remedy in order to prevent such interferences.' 93 Cong. Rec. 4266 (1947), II Leg. Hist. 1077." 172 N.L.R.B. No. 252, at 3 n.4, 69 L.R.R.M. at 1158, n.4.

33 Local 453, Bhd. of Painters (Syd Gough \& Sons, Inc.), 183 N.L.R.B. No. 24, 74 L.R.R.M. 1539 (1970).

34 I83 N.L.R.B. No. 24 at 4, 74 L.R.R.M. at 1540 (1970).

35 Operating Eng'rs Local 501 (Anheuser Busch, Inc.), 199 N.L.R.B. No. 91, 81 L.R.R.M. 1306 (1972); Sheet Metal Workers Local 17 (George Koch Sons, Inc.), 199 N.L.R.B. No. 26, 81 L.R.R.M. 1195 (1972); Pattern Markers' of Los Angeles (Lietzau Pattern Co.), 199 N.L.R.B. No. 14, 81 L.R.R.M. 1177 (1972); Newspaper Guild Local 187 (Times Publishing Co.), 196 N.L.R.B. No. 159, 80 L.R.R.M. 1364 (1972); Lithographers Local 261 (ManhardtAlexander, Inc.), 195 N.L.R.B. No. 80, 79 L.R.R.M. 1342 (1972); Sheet Metal Workers Local 361 (Langston \& Co.), I95 N.L.R.B. No. 65 (1972), 79 L.R.R.M. 1337 (1972); Newark Pressman's Local 8 (Newark Star Ledger), 194 N.L.R.B. No. 89, 78 L.R.R.M. 1715 (1971); Columbia Typographical Local 101 (Evening Star Newspaper Co.), 193 N.L.R.B. No. 167, 78 L.R.R.M. 1562 (1971); Teamsters Local 663 (Continental Oil Co.), 193 N.I.R.B. No. 84, 78 L.R.R.M. 1424 (1971); Bricklayers, Local 7 (United Masonry, Inc.), 193 N.L.R.B. No. 72, 78 L.R.R.M. 1281 (1971); Typographical Local 21 (California Newspapers, Inc.), 193 N.L.R.B. No. 41, 78 L.R.R.M. 1287 (1971); IBEW Sys. Council U-4 (Florida Power Light Co.), 193 N.L.R.B. No. 7, 78 L.R.R.M. 1065 (1971); Sheet Metal Workers Local 71 
its termins, confined to the employer's representatives in collective bargaining and grievance adjustment. Nonetheless, the Board has held that the section applies to union discipline of supervisors for performing any employment related function.

\section{A. The Disciplined Representative}

The Board's early decisions reflect some concern with whether the disciplined supervisor had either collective bargaining or grievance adjustment responsibilities. ${ }^{36}$ Some rank and file unions maintain that section $8(\mathrm{~b})(\mathrm{l})(\mathrm{B})$ was designed to apply only to an employer's high level representatives who are responsible for formulating labor relations policies. $^{37}$ They have sought to distinguish personal grievances that involve "some question of fact or conduct peculiar to the employee, not affecting the unit," from contractual grievances that "raise a question of the meaning of the contract or present a situation not covered by the contract touching which agreement ought to be made." 38 The NLRB has rejected this distinction ${ }^{39}$ and ruled that supervisors

(Otten Co.), 193 N.L.R.B. No. 5, 78 L.R.R.M. 1161 (1971); San Francisco Typographical Local 21 (California Newspapers, Inc.), 192 N.L.R.B. No. 71, 77 L.R.R.M. 1911 (1971); Detroit Newspaper Printing Pressmen's Local 13 (Detroit Free Press), 192 N.L.R.B. No. 2I, 77 L.R.R.M. 1770 (1971); IBEW (Illinois Bell Tel. Co.), 192 N.L.R.B. No. 17, 77 L.R.R.M. 1610 (1971); Locál 2150, IBEW (Wisconsin Elec. Power Co.), 192 N.L.R.B. No. 16, 77 L.R.R.M. 1607 (1971); Printing Pressmen's Local 60 (Herald-News), 190 N.L.R.B. No. 38, 77 L.R.R.M. 1199 (1971); Plumbers Local 100 (McCally, Co.), 188 N.L.R.B. No. 140, 76 L.R.R.M. 1574 (1971); Meat Cutters Local 81 (Safeway Stores, Inc.), 185 N.L.R.B. No. 130, 75 L.R.R.M. 1247 (1970), enforced, 458 F.2d 794 (D.C. Cir. 1972); Bricklayers Local 18 (Lonie \& Son, Inc.), 85 N.L.R.B. No. 119, 75 L.R.R.M. 1336 (1970); Teamsters Local 287 (Grinnell Co.), 183 N.L.R.B. No. 49, 74 L.R.R.M. 1354 (1970); Houston Typographical Local 87 (Houston Shopping News Co.), 182 N.L.R.B. 592, 74 L.R.R.M. 1170 (1970); Dallas Mailers Local 143 (Dow Jones Co.), 181 N.L.R.B. 286, 73 L.R.R.M. 1360 (1970); Sheet Metal Workers Local 49 (General Metal Prods., Inc.), 178 N.L.R.B. 139, 72 L.R.R.M. 1070 (1969); New Mexico Carpenters Council (A.S. Horner, Inc.), 177 N.L.R.B. 500, 71 L.R.R.M. 1470 (1969) and 176 N.L.R.B. 797, 71 L.R.R.M. 1445 (1969), enforced, 454 F.2d 1116 (10th Cir. 1972); Lithographers Locals 15-P \& 272 (Toledo Blade Co.), 175 N.L.R.B. 1072, 71 L.R.R.M. 1467 (1969), enforced, 437 F.2d 55 (6th Cir. 1971); San Francisco-Oakland Mailers' Local 18 (Northwest Publications, Inc.), 172 N.L.R.B. No. 252, 69 L.R.R.M. I157 (1968).

36 Lithographers Locals 15.P \& 272 (Toledo Blade Co.), 175 N.L.R.B. 1072, 71 L.R.R.M. 1467 (1969), enforced, 497 F.2d 55 (6th Cir. 1971).

37 See Lithographers Locals 15-P \& 272 (Toledo Blade Co.), 175 N.L.R.B. 1072, 1078, 71 L.R.R.M. 1467, 1468 (1969), enforced, 437 F.2d 55 (6th Cir. 1971).

38 Hughes Tool Co. v. NLRB, 147 F.2d 69, 73 (5th Cir. 1945). The distinction was also noted by the Supreme Court in Elgin, Joliet \& E. Ry. Co. v. Burley, 325 U.S. 711, 737 (1945), arising under the Railway Labor Act, 45 U.S.C. \$§ 151 et seq. (1970).

39 In Lithographers Locals 15-P \& 272 (Toledo Blade Co.), 175 N.L.R.B. 1072, 71 L.R.R.M. 1467 (1969), enforced, 437 F.2d 55 (6th Cir. 1971), the Board distinguished the issues in Elgin, Joliet \& E. Ry. v. Burley, 325 U.S. 711 (1945) and Hughes Tool Co. v. NLRB, 147 F.2d 69 (5th Cir. 1945) from those involved in the section 8(b)(1)(B) cases: 
who can adjust "on-the-spot" grievances, ${ }^{40}$ whether or not pursuânt to a grievance and arbitration procedure in the collective agreement, are employers' representatives for purposes of section $8(b)(1)(B)$. The Board reasoned that the extent to which union discipline frustrates the employer's assertion of control over persons engaged in resolving disputes on the employer's behalf is unaffected by the origin of the grievance procedure. ${ }^{41}$

The NLRB has also extended section $8(b)(1)(B)$ to cover discipline of supervisors who do not represent the employer in the resolution of any dispute, formal or informal. In Toledo Blade Co., ${ }^{42}$ the Board found that the disciplined supervisors had grievance adjustment responsibilities. It noted, however, that even if the supervisors had not had such responsibilities when they were subjected to union discipline, they were "such natural and potential representatives of the employer for the handling and settlement of grievances . . ."43 that, in the future, the employer would probably delegate grievance adjustment authority to them. The Board concluded that union control over the attitudes of persons likely to be handling grievance matters entails the same risks that Congress perceived when it precluded control over their identity in section $8(\mathrm{~b})(1)(\mathrm{B})$. Toledo Blade indicated that any supervisor with

[T] he distinction between "personal grievance" and "contractual grievances" as it relates to an employer's obligation to bargain collectively only with the exclusive bargaining agent ... has no relevance to the construction of the broad term "grievances" as used not only in the proviso of Section 9(a) of the Act but also in sections 2(11) and $8(\mathrm{~b})(\mathrm{I})(\mathrm{B})$, and that in all three Sections of the Act it must be uniformly construed as including both "personal grievances" and "contractual grievances." 175 N.L.R.B. at 1078, 71 L.R.R.M. at 1469.

40 In Detroit Newspaper Printing Pressmen's Local 13 (Detroit Free Press), 192 N.L.R.B. No. 21, 77 L.R.R.M. 1770 (1971), the union fined an assistant foreman for creating disturbances in the pressroom and for having berated the steward, a fellow union member. The NLRB ruled that the disciplined supervisor was an employer's representative for purposes of section $8(\mathrm{~b})(\mathrm{I})(\mathrm{B})$, since he could adjust on-the-spot complaints occuring during his shift, and therefore found an unfair labor practice.

41 Meat Cutters Local 81 (Safeway Stores, Inc.), 185 N.L.R.B. No. 130, 75 L.R.R.M. 1247, enforced, 458 F.2d 794 (D.C. Cir. 1972). See also IBEW Sys. Council U-4 (Florida Power \& Light Co.), 193 N.L.R.B. No. 7, 78 L.R.R.M. 1065 (1971). The Board has said that the statutory terms are designed to be broadly construed despite the narrower definitions incorporated within a collective bargaining agreement. In Newark Pressmen's Local 8 (Newark Star Ledger), 194 N.L.R.B. No. 89, 78 L.R.R.M. 1715 (1971), the Board rejected the union's argument that a supervisor empowered to deal only with minor complaints excluded from the collective agreement's grievance procedure was not an employer's representative for purposes of adjustment of grievances, finding instead that the company had not "waived its right to deal with employee complaints other than by formal grievances and arbitration procedure," Id., 78 L.R.R.M. at 1716. It therefore ruled that the union had violated section $8(\mathrm{~b})(1)(\mathrm{B})$.

42 Lithographers Locals 15-P \& 272 (Toledo Blade Co.), 175 N.L.R.B. 1072, 71 L.R.R.M. 1467 (1969), enforced, 437 F.2d 55 (6th Cir. 1971).

$13 I d$. at 1079, 71 L.R.R.M. at 1469. 
substantial authority to direct employees' work would come within $8(b)(1)(B)$, but did not define "substantial supervisory authority." 44 Subsequent cases attempted, with the same difficulty, to give substance to that term. ${ }^{45}$ Finally, in Anheuser Busch, Inc., the Board declared that all supervisors are within the category of representatives defined in section $8(\mathrm{~b})(1)(B) .{ }^{46}$

\section{B. The Basis for the Discipline}

Section $8(b)(1)(B)$ was originally linked to disputes arising out of collective bargaining or grievance adjudication; ${ }^{47}$ its application in the supervisor discipline cases has required the Board to define the types of supervisory activities that are protected from union discipline. The Board's initial cases prohibiting union discipline of supervisor-members involved purported violations of the collective bargaining contract. ${ }^{48}$ Application of $8(\mathrm{~b})(\mathrm{I})(\mathrm{B})$ in such circumstances has been justified on the ground that the union had disciplined the supervisors "because of the manner in which they had interpreted and applied the collective bargaining agreement." 49 The argument is, apparently, that because of

44 Id., 71 L.R.R.M. at 1469.

45 In Asbestos Workers Local 127 (Cork Insulating Co.), 189 N.L.R.B. No. 124, 77 L.R.R.M. 1042 (1971), the administrative law judge dismissed a complaint against a union for disciplining a member who violated a union rule requiring members to report work done with a nonunion member. In affirming the administrative law judge's decision, the Board specifically found that the fined individual was not a supervisor within the definition of section 2(11), implying that had the member been designated a supervisor the Board, in light of its Toledo Blade reasoning, might have had to find a violation of section 8(b)(1)(B). In Carpenters Dist. Council (Miner-Dederick Constr. Corp.), 195 N.L.R.B. No. 28, 79 L.R.R.M. 1274 (1972), the administrative law judge found the supervisor's "authority ... was hardly 'substantial' . . . so he was hardly a natural choice to handle grievances." Id., 79 L.R.R.M. at 1276. However, the administrative law judge, uncertain of the meaning of the Board's decision in Cork Insulating Co., supra, noted that his reliance upon the supervisot's limited authority may have been misplaced: "The Board may be of the view that if a man is a supervisor within the meaning of section 2(11), he ipso facto has 'substantial authority.'" Id., 79 L.R.R.M. at 1276. See also Newark Pressmen's Local 8 (Newark Star Ledger Co.), 194 N.L.R.B. No. 89, 78 L.R.R.M. 1715 (1971).

46 Operating Eng'rs Local 501 (Anheuser Busch, Inc.), 199 N.L.R.B. No. 91, 81 L.R.R.M. 1306 (1972). The Board ruled that the union committed an unfair labor practice by disciplining its supervisor for crossing the picket line during a strike and for performing rank and file work.

47 See, e.g., International Typographical Local 38 (Haverhill Gazette Co.) v. NLRB, 278 F.2d 6 (1st Cir. 1960), modifying 123 N.L.R.B. 806, 43 L.R.R.M. 1538 (1959), aff'd, 365 U.S. 705 (1961) (divided Court); Local 294, Teamsters (K-C Refrigeration Transp. Co.), 126 N.L.R.B. 1, 45 L.R.R.M. 1277, enforced, 284 F.2d 893 (2d Cir. 1960); Southern Cal. Pipe Trades Council No. 16, Plumbers (Paddock Pools, Inc.), 120 N.L.R.B, 249, 41 I.R.R.M. 1473 (1958).

48 See, e.g., cases cited at notes 23-26 supra. See Shneidman, Application and Limitation of Union Power, 22 LAB. L.J. 424, 434 (1971).

49 IBEW v. NLRB, - F.2d -, 81 L.R.R.M. 2257, 2261 (1972). See also concurring and dissenting opinion of Judge Wright. Id. at - n.6, 81 L.R.R.M. at 2272 n.6. 
this, the supervisors' contract violation was sufficiently similar to grievance adjustment to warrant $8(\mathrm{~b})(1)(B)$ protection. Even if, however, the supervisors had in fact interpreted the contracts to permit their actions, contract interpretation, although perhaps a necessary component of grievance adjustment, is not synonymous with it. ${ }^{50}$ These initial discipline cases must, therefore, be taken as departures from prior $8(\mathrm{~b})(\mathrm{I})(\mathrm{B})$ decisions.

The requirement that discipline proscribed under $8(\mathrm{~b})(1)(\mathrm{B})$ be connected with bargaining or contract interpretation was abandoned in Meat Cutters Local $81 . .^{51}$ A chain of grocery stores had altered its meat procurement policy and directed supervisors to procure preprocessed meat, thus reducing the amount of work available for union members employed in the store. A supervisor who belonged to Local 81 of the Meat Cutters Union was fined and expelled for implementing the employer's order in contravention of a union policy requiring that grinding and slicing processes be performed in the store. Even though the NLRB's General Counsel did not argue that the supervisor had been disciplined for performing collective bargaining activities or adjusting grievances, ${ }^{52}$ the Board held that section $8(b)(1)(B)$ had been violated since the supervisor had been disciplined for performing his duties as a management representative. ${ }^{53}$ Similarly, in Manhart-Alexander, Inc. ${ }^{54}$ the Board found that a union had violated $8(\mathrm{~b})(\mathrm{l})(\mathrm{B})$ by expelling a supervisor-member for crossing a picket line at the commencement of a strike to aid his employer in closing down the plant.55

The Board's rationale in both cases was that the supervisors, while not performing collective bargaining or grievance adjustment functions, were disciplined for providing services expected of "management representatives." Board decisions involving discipline of supervisors for crossing picket lines to do work ordinarily performed by

50 But see id. at -, 81 L.R.R.M. at 2272 n.6.

61 Meat Cutters Local 81 (Safeway Stores, Inc.), 185 N.L.R.B. No. 130, 75 L.R.R.M. 1247 (1970), enforced, 458 F.2d 794 (D.G. Gir. 1972).

52 IBEW v. NLRB, - F.2d -, - n.6, 81 L.R.R.M. 2257, 2272 n.6 (D.C. Cir. 1972) (concurring and dissenting opinion of Wright, J.), enforcing IBEW (Illinois Bell Tel. Co.), 192 N.L.R.B. No. 17, 77 L.R.R.M. 1610 (1971).

63 Meat Cutters Local 81 (Safeway Stores, Inc.), 185 N.L.R.B. No. 130, 75 L.R.R.M. 1247, 1248 (1970), enforced, 458 F.2d 794 (D.C. Cir. 1972).

54 Local 261, Lithographers (Manhardt-Alexander, Inc.), 195 N.L.R.B. No. 80, 79 L.R.R.M. 1342 (1972).

55 Member Fanning concurred, noting that the work performed by the disciplined supervisors could not be characterized as struck work within the meaning of his opinions in Local 2150, IBEW (Wisconsin Elec. Power Co.), 192 N.L.R.B. No. 16, 77 L.R.R.M. 1607 (1971), and IBEW (Illinois Bell Tel. Co.), 192 N.L.R.B. No. 17, 77 L.R.R.M. 1610 (1971). 195 N.L.R.B. No. 80, at 3, 79 L.R.R.M. at 1343. 
rank and file employees ${ }^{50}$ represent àn even greater expansion of $8(\mathrm{~b})(\mathrm{I})(\mathrm{B})$. In these cases, the Board rested its conclusion on the ground that the supervisors could not be disciplined "for performing work which their [e]mployer had directed them to perform."

The Board's analysis has received the approval of the Court of Appeals for the District of Columbia, which granted enforcement of the Board's order in $I B E W$ v. $N L R B .58$ In $I B E W$, the supervisor had been disciplined for performing struck work, for which, under AllisChalmers, the union could fine employèe-members. The court stated that the employer had a legitimate right "to call upon the undivided loyalty of its representatives" $"$ to further its interests and that supervisory employees engaging in rank and file work during a strike "are performing in a manner which could reàsonably be expected from such persons." 60

The Board's use of section $8(\mathrm{~b})(\mathrm{l})(\mathrm{B})$ in supervisor-discipline cases presents problems of statutory interpretation. As noted above, the section was intended to serve a quite limited purpose. Congress desired to restrict union attempts to assert control over employers' sélection of persons to represent him in dealings with the union. While the TaftHartley Act generally does not purport to affect the substance of collective bargaining agreements, ${ }^{01}$ it does regulate the parties' tactics, prohibiting those deemed sufficiently offensive to pose an unwarranted threat to labor peace.

There is considerable justification for the Board's application of section $8(\mathrm{~b})(\mathrm{I})(\mathrm{B})$ to cases in which unions have used their disciplinary power as a means of controlling supervisors to whom an employer had given some responsibility for bargaining or grievance adjustment. Such use of the disciplinary power can, at least arguably, impair labor peace to the same extent as attempts to control the identity of employer representatives. As the Board recognized in San Francisco-Oak-

56 IBEW Sys. Council U-4 (Florida Power \& Light Co.), 193 N.L.R.B. No. 7, 78 L.R.R.M. 1065 (1971); IBEW (Illinois Bell Tel. Co.), 192 N.L.R.B. No. 17, 77 L.R.R.M. 1610 (1971), enforced, - F.2d -, 81 L.R.R.M. 2257 (D.C. Cir. 1972); Local 2150, IBEW (Wisconsin Elec. Power Co.), 192 N.L.R.B. No. 16, 77 L.R.R.M. 1607 (1971).

57 E.g., Local 2150, IBEW (Wisconsin Elec. Power Co.), 192 N.L.R.B. No. 16, at 6, 77 L.R.R.M. 1607, 1609 (1971). The Board reasoned that "the supervisors, by doing struck work, as directed by the Employer, were furthering the interests of the Employer in a dispute not between the Union and the supervisor-union members but between the Employer and the Union," Id., 77 L.R.R.M. at 1609, and said that this would be true even if the employer had agreed to a union security provision including supervisors. 192 N.L.R.B. No, 16, at 5, 77 L.R.R.M. at 1608-09.

58 IBEW v. NLRB, - F.2d,- 81 L.R.R.M. 2257 (D.C. Cir. 1972).

5B Id. at -, 81 L.R.R.M. at 2265.

60̀ Id. But see Gould, supra note 19, at 1129 .

61 H.K. Porter Co. v. NLRB, 397 U.S. 99 (1970). 
land Mailers', both tactics can be seen as simply alternative means to the same end; both involve many of the same conflicting employer and union interests. ${ }^{62}$ The Board's subsequent extension of $8(\mathrm{~b})(1)(B)$, however, seems less justifiable. In cases in which unions had disciplined supervisors for actions unrelated to bargaining or grievance adjustment, and particularly in cases in which the supervisor had no bargaining or grievance adjustment responsibility whatever, application of $8(b)(1)$ (B) lacks support from either the text or the legislative history of the Act.

The unsuitability of section $8(b)(1)(B)$ to deal with the more general problem of union control over supervisors accounts for the Board's difficulty in articulating clear standards for its application. The use of the section to reach all union discipline of supervisors appears to be an attempt to give force to considerations that the Act implicitly recognizes, but for which it provides no specific enforcement mechanism. As the District of Columbia Circuit said in upholding a finding that discipline of a supervisor constituted a violation of $8(b)(1)(B)$ : " $[I] t$ is readily apparent, when all the relevant 1947 amendments to the Act are considered in concert, that Congress did not intend thereby to allow unions to subvert the 'undivided loyalty' it clearly believed such managerial personnel owed to their respective employers." 3

The court seems correct in asserting that the 1947 amendments, if not $8(\mathrm{~b})(1)(\mathrm{B})$ specifically, provide a basis for proscribing discipline of supervisors even if they do not represent management for grievance or bargaining purposes. The discussions surrounding adoption of section 2(3), which eliminates supervisors from the category of protected employees, section 2(11), which separately defines supervisors, and section 14(a), which allows supervisors to be union members and provides that employers may not be forced to recognize supervisors as employees for collective bargaining, reflect concern over the relative extent of employer and union control of supervisors. These sections of the Act are the result of congressional balancing of the employer's interest in securing the loyalty of his supervisory officials, the interests of the supervisor in association vel non with a union, and the rank and file union's interests in obtaining supervisors' support.

As indicated above, ${ }^{64}$ Congress's primary concern in the 1947 amendments was to enable management to carry out its wishes free of conflicting claims upon the loyalty of its chosen agents. At the same time,

62 San Francisco-Oakland Mailers' Local 18 (Northwest Publications, Inc.), 172 N.L.R.B. No. 252, 69 L.R.R.M. 1157 (1968).

63 Meat Cutters Local 81 v. NLRB, 458 F.2d 794, 800 (D.C. Cir. 1969).

64 See text and notes at notes 7-9 supra. 
however, Congress wanted to safeguard supervisor and employee interests as well as to preserve long-established associations existing in some industries. ${ }^{65}$ These conflicting concerns led to the adoption of a patchwork of legislative provisions. Management's freedom of action was compromised by provisions allowing continued supervisor-union relationships that could impose significant burdens on that freedom. The supervisor-discipline cases have involved the search for a resolution to this tension.

The Act allows conflicts to exist between union and employer, but provide procedures into which disputes are channeled. Collective bargaining and the contractual, administrative, and judicial remedies for identifying and penalizing breach of collective bargaining contracts are the primary means that the labor laws prescribe for conflict resolution. Union discipline of supervisors interferes with this pattern in two ways. When a supervisor is disciplined for bargaining or adjusting grievances for the employer, the bargaining process is undermined by depriving the employer of effective representation. In such cases section $8(b)(l)(B)$ is violated. When a supervisor is disciplined for other actions taken in the course of his employment, the bargaining process is circumvented. This second type of interference with orderly collective bargaining should not be considered prohibited by $8(\mathrm{~b})(1)(\mathrm{B})$. It is not a bargaining tactic, but rather a device, outside the bargaining process, for attaining union objectives. As such it should be held subject to the strictures of section $8(\mathrm{~b})(3) .{ }^{66}$

This section, unlike $8(\mathrm{~b})(\mathrm{I})(\mathrm{B})$, was designed broadly to prevent unjustified circumvention of the bargaining process. Both employers and unions are required by the Act to engage in good faith bargaining concerning wages and other conditions of employment-employers under $8(a)(5)^{67}$ and unions under $8(b)(3)$. An employer cannot refuse to bargain about such subjects with any majority union representing the affected employees. ${ }^{68}$ And some employer actions, such as subcontracting for a substantial proportion of work normally performed by company employees, effect so great a change in employer-employee

65 Prior to the passage of the Taft-Fartley amendments in 1947, foremen generally maintained membership in employee unions and were included in contracts covering rank and file employees in a number of industries, including printing and building trades and metal trades insofar as they operated on a craft basis. With regard to teamsters and longshoremen, the practices varied. U.S. Dep't of Labor, Bulletin No. 745, Union Membership \& Collective Bargaining by Foremen 1 (1943), cited in Nassau \& Suffolk Contractors' Ass'n, Inc., 118 N.L.R.B. 174, 180 n.21, 40 L.R.R.M. 1146, 1148 n.21 (1957); see Comment, supra note 5 , at 764, 772.

6629 U.S.C. § 158(b)(3) (1970).

6729 U.S.C. $\$ 158(\mathrm{a})(5)(1970)$.

68 See NLRB v. Katz, 369 U.S. 736 (1962). 
relationship that the employer must bargain with the union before taking them. ${ }^{69}$ At the same time, unions cannot require the employer to bargain about subjects not related to wages and other conditions of employment; ${ }^{70}$ if they attempt to do so, their action is outside the scope of activity protected by the Act. ${ }^{71}$ In addition, unions cannot, during the contract's term, demand that employers agree to changes in items covered by a valid collective bargaining agreement. ${ }^{\mathbf{2}}$

Like massive subcontracting, union discipline of supervisors for performing work as directed by management or exercising discretion delegated by management is an attempt to restructure the relationship between the employer and employees. ${ }^{73}$ It allows the union to exercise essential control over the operations of the business. ${ }^{74}$ To the extent that the Board's $8(b)(1)(B)$ decisions indicate that the union's power to discipline supervisors is not a mandatory subject of bargaining because unrelated to wages and conditions of employment, unions may not bargain to impasse in order to obtain it. If such union disciplinary power is a mandatory subject of bargaining-if it relates to wages and conditions of employment-then the union may not exercise it unless the employer, in a collective bargaining agreement, has clearly assented or the union has bargained to impasse. In the absence of the employer's assent or, at least, impasse, the union's discipline of supervisors subverts the bargaining process in violation of $8(b)(3)$ : it is an attempt by the union to avoid whatever grievance adjustment and arbitration mechanisms its contract with the employer may contain

60 Fibreboard Paper Prods. Corp. v. NLRB, 379 U.S. 293 (1964).

70 NLRB v. Hod Carriers Local 1082, 384 F.2d 55 (9th Cir. 1967), cert. denied, 390 U.S. 920 (1968); see NLRB v. Wooster Div. of Borg-TWarner Corp., 356 U.S. 342 (1958).

71 Compare Fibreboard Paper Prods. Corp. v. NLRB, 379 U.S. 293 (1964); American News Co., 55 N.L.R.B. 1302, 14 L.R.R.M. 64 (1944).

72 Jacobs Mfg. Co., 94 N.L.R.B. 1214, 28 L.R.R.M. 1162 (1951), enforced, 196 F.2d 680 (2d. Cir. 1952).

73 In NLRB v. Insurance Agents Int'1 Union, 361 U.S. 477, 497 n.28 (1960), the Supreme Court left open the question whether a union's imposition of new terms and conditions violates $8(\mathrm{~b})(3)$ as an employer's violates 8(a)(5). But see Associated Home Builders, Inc. v. NLRB, 352 F.2d 745 (9th Gir. 1965). Compare Ben Cutler v. NLRB, 395 F.2d 287 (2d Cir. 1968). See generally C. MoRRIs, supra note 12, at 326-27.

74 Unions normally exercise their influence on the direction of the employer's operation through the contract. Union actions designed to procure the employer's agreement to a change in working conditions are viewed only as presenting a demand to the employer; they do not consitute a violation of 8(b)(3). Ben Cutler v. NLRB, 395 F.2d 287 (2d Cir. 1968) (union amended bylaws during contract negotiations to specify higher wage scale and to establish new welfare fund). Union attempts unilaterally to change the employment relationship do, however, violate $8(\mathrm{~b})(3)$. For example, a union's unilateral imposition of production quotas, enforceable by fines, constitutes a refusal to bargain in violation of 8(b)(3). Associated Home Builders, Inc. v. NLRB, 352 F.2d 745 (9th Cir. 1965). See also C. MoRrss, supra note 12, at 326-27. 
and to restrain the employer's action on valid subjects of bargaining without any attempt to bargain. By using section $8(\mathrm{~b})(3)$ to deal with supervisory discipline outside the scope of section $8(\mathrm{~b})(\mathrm{l})(\mathrm{B})$, the Board could openly balance the asserted interests and determine whether the union's action in a given case is justified in light of possible harm either to orderly bargaining or to the substance of the bargain, including agreed enforcement mechanisms.

\section{Participation by Supervisors in Union Affairs}

The limitations that the Board has imposed on unions' power to discipline supervisors create tensions with Board decisions concerning the permissible extent of supervisors' participation in union affairs. Section 14(a) of the Act, which allows supervisors to be union members, ${ }^{75}$ contains no guidelines for determining the meaning of the term "membership." Most questions of supervisors' participation in employee unions have been raised in proceedings under section $8(a)(2),{ }^{76}$ proscribing employer interference with or domination of a union, and section $8(a)(1),{ }^{77}$ prohibiting employer interference with employees' exercise of their section $7^{78}$ organizational and bargaining rights.

In Nassau \& Suffolk Contractors' Association, ${ }^{79}$ the Board ruled that no supervisor-member can serve on the union's negotiation committee and that the employer's acquiescence in such participation constitutes interference with the administration of the union, in violation of section 8(a)(2). The Board concluded that the loyalty of supervisors to management inevitably prevents them from being the union's most effective negotiators. ${ }^{80}$ Although the Board excluded both high- and low-level supervisors from contract negotiations, ${ }^{81}$ it allowed low-level supervisors to engage actively in internal union affairs absent proof of

75 See note 13 supra.

7629 U.S.C. § 158(a)(2) (1970).

7729 U.S.C. $\$ 158(\mathrm{a})(1)(1970)$.

7829 U.S.C. $\S 157$ (1970).

79118 N.L.R.B. 174, 40 L.R.R.M. 1146 (1957); see Daykin, Legal Meaning of "supervisor" Under Taft-Hartley, 13 LAB. L.J. 130, 132 (1962).

80 Although it found employer interference, the Board refused to find employer domination. "[E]mployees have the right to be represented in collective bargaining negotiations by individuals who have a single-minded loyalty to their interests." 118 N.L.R.B. at 187, 40 L.R.R.M. at 1151. See also Banner Yarn Dyeing Corp., 139 N.L.R.B. 1018, 102627, 51 L.R.R.M. 1457 (discussion omitted) (1962), in which the Board noted that a super, visor may hold any union office-even those that, under the union constitution, have contract negotiation responsibilities-so long as the supervisor does not engage in actual negotiations.

81118 N.L.R.B. at 187, 40 L.R.R.M. at 1151. 
employer encouragement, authorization, or ratification. ${ }^{82}$ Low-level supervisors have, according to the Board, a right to a "voice and a vote in the administration of the affairs of the union." 83 The Nassau doctrine has allowed low-level supervisors to attend union meetings, ${ }^{84}$ hold union office, ${ }^{85}$ and engage in other forms of union activity ${ }^{86}$ when. ever the rank and file union represents them in collective bargaining. Moreover, the Board has permitted the participation of low-level supervisor-members even though they are not included in the same bargaining unit with rank and file employees. ${ }^{87}$

The Board has rejected the contention that its Nassau holding is precluded by the Landrum-Griffin Act's ${ }^{88}$ guarantee of "equal rights and privileges within such organization" to all union members. ${ }^{89} \mathrm{In}$ stead, the Board has construed that guarantee to apply only to rank

$82 \mathrm{Id}$. at 183, 40 L.R.R.M. at 1149. In the context of union organizational campaigns, the Board has drawn a similar distinction between the limited impact upon rank and file employees of participation by low-level supervisors as contrasted with that of upper echelon representatives. E.g., Flint Motor Co., 194 N.L.R.B. No, 115, 79 L.R.R.M. 1040 (1972); Turner's Express, Inc., 189 N.L.R.B. No. 23, 76 L.R.R.M. 1040 (1971), enforced, 456 F.2d 289 (4th Cir. 1972). In Turner's Express, the Fourth Circuit rejected this distinction, reasoning that employees are more concerned with the attitude of their immediate supervisors than with that of high-level company officers. Turner's Express, Inc. v. NLRB, 456 F.2d 289 (4th Cir. 1972), relying on NLRB v. Roselon S., Inc., 382 F.2d 245 (6th Cir. 1967) and NLRB v. Heck's, Inc., 386 F.2d 317 (4th Cir. 1967).

83118 N.L.R.B. 174, 181, 40 L.R.R.M. 1146, 1148 (1957).

84 National Gypsum Co., 139 N.L.R.B. 916, 51 L.R.R.M. 1405 (1962).

85 Banner Yarn Dyeing Corp., 139 N.L.R.B. 1018, 51 L.R.R.M. 1457 (1962).

86 In Geilich Tanning Co., 122 N.L.R.B. 1119, 43 L.R.R.M. 1262 (1959), remanded, 276 F.2d 34 (1st Cir. 1960), the NLRB found no violation of section 8(a)(2) where a working foreman, included in the bargaining unit, moved to renegotiate the collective bargaining agreement. The First Circuit affirmed the Board's application of the Nassau doctrine.

87 Mechling Barge Lines, Inc., 197 N.L.R.B. No. 89, 80 L.R.R.M. 1656 (1972). The result in this case is a consistent extension of previous decisions. For example, in Local 636, Plumbers v. NLRB, 287 F.2d 354 (D.C. Cir. 1961), the District of Columbia Circuit provided additional guidelines for the Board, suggesting that "(l) the nature of the supervisory position . . . (2) apparent permanence of the position . . . and (3) the extent to which it is properly included or excluded from the bargaining unit . . " are relevant factors for consideration. $I d$. at 362. It added that the third factor was based in part on the first factor, perhaps implying that the Board should not rely exclusively on the consent agreement between the employer and the union for purposes of determining which supervisors may participate in union affairs.

Although both Nassau and Local 636, Plumbers arose in the building trades, the Board's Nassau doctrine has been applied in other industries as well. See, e.g., Pangles Master Mkts., Inc., 190 N.L.R.B. No. 58, 77 L.R.R.M. 1595 (1971); National Gypsum Co, 139 N.L.R.B. 916, 51 L.R.R.M. 1405 (1962); Geilich Tanning Co., 122 N.L.R.B. 1119, 43 L.R.R.M. 1262 (1959), remanded, 276 F.2d 34 (1st Cir. 1960); Montgomery Ward Co., 115 N.L.R.B. 645, 37 L.R.R.M. 1370 (1956), enforced, 242 F.2d 497 (2d Cir. 1957).

88 Labor-Management Reporting and Disclosure Act (Landrum-Griffin Act), 29 U.S.C. $\S \S 401$ et seq. (1970).

$80 \S 101(a)(1), 29$ U.S.C. $\$ 411(a)(1)(1970)$. 
and file members, relying on the express statement in LandrumGriffin that it does not "affect the rights of any person under the National Labor Relations Act, as amended."90 Unless the NLRA gave supervisors a right to participate in union affairs, then no right of equal participation was conferred by the Landrum-Griffin Act. The NLRA does not speak to the question of supervisors' participation, but only to their membership in unions. ${ }^{91}$ While the Landrum-Griffin Act's provision purporting not to affect rights under the NLRA could be considered consistent with finding supervisor-members guaranteed the same internal rights as other union members, there is no indication that, in drafting Landrum-Griffin's equal rights guarantee, particular attention was paid to the special problems presented by supervisors.

The Board has not based its decisions concerning supervisor participation in union affairs on any particular statutory command. Instead, it has attempted in these decisions to balance several interests recognized implicitly or explicitly in the Act-the employees' interest in free exercise of their section 7 rights, the supervisors' interest in union affiliation, and the employers' interest in supervisors' loyalty. Participation in union affairs by supervisors who are responsible to and act on behalf of management may prevent the union from effectively representing rank and file employees. The mere presence of supervisors at union meetings may inhibit employees in their discussion of work-related issues, and management-oriented supervisors could conceivably hold the deciding votes in union decisions. The Board has found these threats to employee rights sufficient to bar from participation upperechelon supervisors, who are closely aligned with management. At the same time, it has concluded that employee interests are insufficient to bar all participation by lower-level supervisors, who "owe allegiance at least as much to the union as to their employers." ${ }^{2}$ Such supervisormembers may want to participate in union affairs in order to help safeguard their interests in competent union management-especially when the union represents them in bargaining with the employer.

The Board's recent decisions regarding discipline of supervisors, however, rest on the assumption that there is a close relationship

90 § 603(b), 29 U.S.C. § 523(b) (1970); see Banner Yarn Dyeing Corp., 139 N.L.R.B. 1018, 1025 n.28, 51 L.R.R.M. 1457 (discussion omitted) (1962); Beaird, Union Officer Election Provisions of the Labor-Management Reporting and Disclosure Act of 1959, 51 VA. L. Rev. 1306,1317 \& $\mathrm{n} .41$ (1965).

o1 The District of Columbia Circuit interpreted the Landrum-Griffin Act to "amplify" rather than "change" the intent of the Taft-Hartley Act. Local 636, Plumbers v. NLRB, 287 F.2d 354, 360 (D.C. Cir. 1961).

92 Nassau \& Suffolk Contractors' Ass'n, 118 N.L.R.B. 174, 182, 40 L.R.R.M. 1146, 1149 (1957). 
between management and all of its supervisors. Given the tension between these two lines of decisions, the Board should reexamine its holdings concerning supervisors' participation in union affairs. The Board may want to permit continued participation by supervisors in union decision making in certain cases, particularly in firms in which supervisors and employees form a fluid group with frequent changes in status. But, as a general rule, supervisory participation should perhaps be curtailed. If, as the Board indicates in its $8(b)(1)(B)$ cases, all supervisors act as important agents of management and if the inability of unions to discipline supervisors reduces the benefit supervisors can obtain from unions, then their interests do not support the extensive participation in union affairs that the Board has heretofore allowed.

Without the support of rank and file employees, supervisors can assert their economic power alone or depend on the employer to set their compensation. Since the employer is interested in attracting qualified supervisors, the compensation offered must be sufficient to induce a worker to accept the position. Employees' success in improving their own wages and working conditions will, presumably, raise the floor for their supervisors' salaries. The primary quid pro quo for which employees, through their unions, might undertake to raise supervisors' salaries still higher is the support of those supervisors. Because union discipline of supervisors has been curtailed, employees cannot confidently bargain for benefits for supervisors in exchange for their future loyalty to union causes. Of course, the union retains the power to offer other inducements, such as friendships and the promise to supervisors of future bargaining efforts in their behalf. Nonetheless, supervisors cannot be certain that such future consideration for present support will become an actuality. Thus, without the power to impose sanctions, the union may not feel able to rely on supervisors' promises of future support in return for current bargaining assistance; and the supervisor may not feel able to rely on the union.

To the extent that this is in fact the case, the union's interest in obtaining present benefits for supervisors has decreased because of the removal of union discipline as a mechanism for enforcing loyalty. At the very least, the interests of supervisors and rank and file employees appear more divergent than they would be if unitary action could be enforced. This possible reduction in the union's incentive to bargain, or to bargain forcefully, for benefits to supervisors results in a corresponding reduction in the advantage to supervisors of being represented by unions and, hence, of participation in union decisions. Although supervisors' interests in matters such as governance of pension and welfare funds are undiminished by the Board's $8(\mathrm{~b})(1)(\mathrm{B})$ de- 
cisions, the Board may want to weigh separately the probable benefits to supervisors of participation in such decisions against the diffculty of allowing participation in only selected matters.

If supervisors' interests in participation have been lessened as a result of the discipline decisions, employee interest in preventing such involvement has increased. The decreased employee control over supervisor-members heightens the conflict between the interests of employees and management-oriented supervisor-members. Moreover, whatever interest employees have in minimizing supervisors' participation when unions lack effective sanctions coincides with the employer's interest in minimizing supervisors' union ties. Employees fear the possible use of supervisors as management spies. While employers may desire to use supervisors for such purposes, their only legitimate interest relevant to this problem is in securing the loyalty of their supervisory personnel or eliminating conflicting union allegiance. In many industries at least, further limitation of permissible supervisory participation in the affairs of employee unions will comport with the interests recognized by the Act and will reduce the tension between the Board's decisions on discipline of supervisors and on supervisors' union participation. ${ }^{93}$

\section{Concluston}

In recent decisions, the Board has indicated a commitment to prevent unions from requiring loyalty from supervisor-members when the union's actions may interfere with management's operation of its business. Support for this policy can be inferred from the history of the Taft-Hartley Act and from several of its provisions. In its attempt to implement this policy, the Board has expanded far beyond its intended scope section $8(\mathrm{~b})(1)(B)$, which was added to the NLRA by the Taft-Hartley Act. Section 8(b)(3)'s design makes it an appropriate provision for preventing union interference with management operations when such interference is beyond the scope of $8(b)(1)(B)$. Use of $8(b)(3)$, rather than extension of $8(\mathrm{~b})(1)(\mathrm{B})$, would be more consistent with the statute's terms and history and would allow the Board to more candidly

93 While placing limitations upon supervisory participation in the affairs of rank and file unions will aid in severing ties between rank and file employees and their supervisors, this solution may have adverse consequences as well. Unions might be temporarily injured should limitations be imposed since supervisor-members are often active supporters of the union. More importantly, supervisors deprived of association with their unions, may find it necessary to form separate organizations and join forces with rank and file unions both at and away from the bargaining table in an effort to maximize their strength. If it proscribed participation in employee unions, the Board might be forced to police the relationships between supervisory and employee unions. 
explain the policy considerations underlying its prohibition on discipline of supervisors by employee unions. Finally, in light of its recognition in supervisor-discipline decisions of the strength of the employer's need for loyal supervisors and the effect those decisions may have in lessening supervisors' potential benefits from participation, the Board should reexamine its holdings on supervisory participation in the affairs of rank and file unions.

Phillip E. Garber 